MATEC Web of Conferences 53, 01026 (2016)

DOI: $10.1051 /$ matecconf/20165301026

(C) Owned by the authors, published by EDP Sciences, 2016

\title{
Problems and solutions of multi storey buildings: Okhta business center integration in historical center of Saint Petersburg
}

\author{
Daria Anishchenko $^{1, a}$, Egor Batkov ${ }^{1}$, Maria Kukushkina ${ }^{1}$ and Artem Korsun ${ }^{1}$ \\ ${ }^{1}$ Peter the Great St. Petersburg Polytechnical University, Polytechnicheskaya st. 29, 195251, St. Petersburg, Russia
}

\begin{abstract}
This research is an attempt to make the analysis of possible solutions to the problem of the land where the Okhta Center was to be constructed. The authors studied the case from the historical, practical and cultural sides. In order to find out the current public opinion on this matter two surveys were held both among St Petersburg residents and foreign guests of the city. The main aims of this article were to find the solutions, that would lead to improvement in the cultural and social level of St Petersburg citizens' life. The possible outcomes of this research are increasing incomes of the city budget, raising the status of the city and the development of Krasnogvardeisky region of St. Petersburg.
\end{abstract}

\section{Introduction}

The Nowadays the society needs to balance historic, cultural and modern urban aspects of the life of the city. Sometimes it means that every aspect could destroy another just because of the opportunity of the future profit from it. Of course, the profit is not only money matter, but also involves the reputation of the city and region in general, that also could reflect the economic stability of the region and nearby areas.

One of the best examples of the failure of the city to find the balance between culture, history and business is the Okhta Center. In 2010, Gazprom Company started the erection of a high skyscraper that was supposed to be the tallest tower in Europe, but citizen and archeological government funds stopped all works on the territory of the Okhta Cape. The main official reason was seven archeological layers discovered in the area and the possibility of their contribution to the development of Russian archeology and provide more information about life of ancient people in the Northern region.

As a result, the UNESCO, brought charges to the government of Saint Petersburg. According to them, the Okhta Center destroyed the exterior of Saint Petersburg skyline. They disapproved the idea, that the tower would be seen from all historical parts of the "Northern Venice" [1].

The main tendency in the architecture of Saint Petersburg is preserving the original look of the buildings and following the original plan. Saint Petersburg was the first thoroughly planned city in Russia. That is why even new buildings are sometimes constructed in baroque or neo classicism stiles to match in style with the surrounding buildings. This tendency is different from many other big cities like London, Paris, Madrid where contemporary architecture finds good balance with old architecture.

\footnotetext{
${ }^{a}$ Corresponding author : impurus@rambler.ru
} 
All this cities have skyscrapers side by side with old architecture buildings; they find a solution in the balance of modern and old, economic and cultural requirements.

This paper analyze the reasons for the failure of large-scale project such as the Okhta Center and on the basis of public opinion, as well as taking into account the needs of the city, will offer few versions of the Okhta Cape. Therefore, an analysis of public opinion of citizens on the future destiny of the construction site Krasnogvardeisky region of St. Petersburg was held. In addition, it was reviewed and subjected to a thorough analysis of the arguments and submissions of the parties of the conflict, as well as reported and estimated accounting, after which the best option of the territory had been identified. The option includes taking into account features as well as archaeological value of the area, which was described in next paragraph.

\section{Methods and materials}

\subsection{History of The Okhta Cape}

The deepest archeological layer dates back to Neolithic Age, between IV and III millennium BC (the Baltic Sea was named Littorina sea at that time[2]). It represents life of ancient people in the North of Europe, whose main occupation was fishing. That is why fishing tools were found, such as plummet and trap for fish. The form of the plummet indicated the fact, that people on this territory used fishing bot and fishing nets. In addition, archeologist found a fish trap. It composed from wood sticks, which was thrust in the ground.

Together with fishing tools, ceramics, pendants made of amber and have trapezoidal or surround shape with V-form holes were found on this side

Besides the tools, such as special stone for wood processing, and ceramics, on Okhta Cape were excavated 40 building constructions: older living and industrial space and younger structures like houses, industrial and support structures [3].

Between Bronze and Rome Age only several single excavations were done.

In 1300, Royal governor Tergils Knutson came with 1100 warrior to build a temple. Sweden chronicler marked that Landskrona had moat and wall with eight towers. After ending of the construction, in the Landskrona based 300 warriors. Landskrona was destroyed the next year by Andrei, who was son of Alexander Nevskiy, the great Russian warrior and the patron saint of St Petersburg.

Today archeologists assume that under this fortification was another one, which could belong to Novgorod or Izhora, which was satellite of Novgorod. This layers include moat and earth wall.

This location couldn't stand along for a long time. So, in the 1500 chronicler noted about new commercial center in this place named Nevskoe Ustie. There were few settlement, where merchants fulfilled international transactions.

The excavations of this this period include ceramics made from red clay and kaolin [4].

The erection of Nyenschantz started during The Ingrian War, in 1611. The deficit of qualified workers and building material stopped construction, but in the end of 1611 the fortress could save 500 people and was almost end.

During next years Nyenschantz was mentioned in military correspondence.

In the 1644, planning of the fortress was presented. It looked like a square fortress with heptahedral towers on its corner and had three defensive front:

- moats and earth bank, which covered a city and fortress inside.

- fortification, including pentagonal fortress, four bastion and three ravelins

- old castle inside the fortress

Archeologists don't know the condition of Nyenschantz in 1661, but the fortification might have stayed unfinished.

After the ending of The Russo-Swedish War of 1656-1658, Nyenschantz still was the property of Sweden. And in 1659 a governor of the province got the order to strengthen Nyenschantz, named as 
the "significant and important" city, and the construction of the fortress continued. At that time, it had seven big "king" bastions and the earth bank.

The reconstruction and consolidation of the fortification had been continuing before the city was burnt in 1702.

The city near fortress was burnt in 1702 because the threat of the Russian attack, which started only years after [5].

After this day, the excavations lost their value for the Archeology, and this place has become important just for the Hisrory.

In 1727, dockyards were built on the territory of the Okhta Cape. It built rowing and sailing vessels such as schooners, centerboard boats etc. The Okhta Admiralty was created on the base of old dockyards. It built well-known sloop "Vostok", which was include to The First Russian Antarctic Expedition.

In the Soviet time it was named Petrozavod. After 1931, it started building of tugs, passenger's boats and liners.

During Great Patriotic War, the Petrozavod produced casing of mines, bombs, missiles, built pontoons for the evacuation from the besieged Leningrad and the delivering of the food to the city, repaired ships [6].

In 2006, Gazprom Company bought the Petrozavod. The industrial zone had been degraded by this time, and new owners had the idea of building a new the huge business center. It was to fulfill the requirements of the government to develop this region of Saint Petersburg [7].

Project of the Okhta Center had placed on 66.8 hectares. For its main part, which included a skyscraper and a nearby building, was disposed 4.6 hectares. According to the planning, the Gazprom Company and its sub companies had 16 percent of all the square, $35 \%$ were planned to be placed for public use; other part of the square was used for the business center. The requirements of the modern business were fulfilled with this office area and made better conditions for attracting new taxpayers to the city.

The first zone of the project included: offices of "Gazprom" and its subsidiaries, the shopping and entertainment centre, the library, athletic facilities, the parking space.

The biggest Russian and World companies were supposed to hold space in the building that could provide workplace for more than 8500 specialists.

The building of the skyscraper should have been finished until the end of 2012. All project should have been finished until the end of 2016.

In December of 2010, works on the building site were stopped by the order of the Saint Petersburg's governor.

The following part of this paragraph is a chronology of actions and events associated with the construction of the Okhta Center, which took place from 2005 to 2009.

November 15, 2005 - the competition for the development of the architectural concept of the administrative and business center "Gazprom-City" was announced. June 14, 2006 - the announcement of the results of the contest first stage for the preliminary concept of the center "Gazprom-City". From forty-six participants of the commission has selected the most promising projects. The British architectural bureau RMJM London won the Architectural design competition "Gazprom-City" project [8].

December 18, 2006 - the publication of the results of the sociological research "Social Information Agency". "According to the survey, the number of opponents and supporters of "Gazprom-City": 33\% of peoples support the idea of the construction of St. Petersburg, 35\% against the act. The relative given error of sociological research (it was 2.5\%), we can conclude that with respect to the project "Gazprom-City" of the St. Petersburg population equally divided "(IA Regnum, 18.12.2006). At the same time, according to the study, $51 \%$ of the St. Petersburg young people supports the idea of the construction, while against the idea expressed only $25 \%$. This is a good indicator expressing the needs of the city and the benefits of this project.

This information makes it possible to imagine how massive the project was and what aspects of the cultural and social life of the city it raised. However, one of the arguments of the opponents of the 
project was a huge price because it was planned to be fully financed from the city budget, but as we see, the first half, and then the entire construction cost of this project were carried out by Gazprom:

As a matter of fact, in 2007 St. Petersburg governor, Valentina Matvienko, introduced the Legislative Assembly of the city with the draft Law of St. Petersburg "On Amendments to the Law of St. Petersburg "On Target Program of St. Petersburg "Construction of the administrative business center in St. Petersburg"'. According to the law, the main executor of the activities of the program becomes the project of "Cultural and Business Center Okhta ". It is worth mentioning that $49 \%$ of the share capital were to be owned by St. Petersburg and 51\% - by JSC "Gazpromneft" [9].

However, the pressure on the government and criticism of the residents were conducted for a long time and in many ways. Especially important to mention is the letter from the Union of Architects, as well as the views of the head of the British architectural bureau Wilkinson Eyre Architect Chris Wilkinson and the opinion of the UNESCO about the importance of the project and its implementation in the whole the territory.

Back in July 2006, Valentina Matvienko was sent a collective appeal of the St. Petersburg Union of Architects, signed by its president, Vladimir Popov, alleging that the skyscraper would ruin the city's appearance. This idea was soon supported by the Union of Architects of Russia, in a letter which kept information about the competition broke all international and national rules and regulations. In protest Union boycotted the competition, which is why all the projects were foreign.

In January 2008, Chris Wilkinson, the head of the British architectural bureau Wilkinson Eyre Architect, during the interview to REGNUM correspondent assumed: "While developing any project, it is necessary to preserve as much as possible from the architectural heritage of the past and modern architecture needs to be very sensitive ... So in this case, in the case of the project skyscraper. Everything will depend on its location relative to the center of St. Petersburg. The farther the building, the better" [10].

In June 2007, New Zealand housed the 31th session of the World Heritage Committee of UNESCO. The decision of the session on the project of the World Heritage "Historic Centre of Saint Petersburg and Related Groups of Monuments" noted that: "The plans provided by a member state of 18 January 2007 and 5march 2007 do not comply with the committee and do not contain any clear boundaries and buffer zones of the objects in general, including the Leningrad Region". UNESCO adopted the strong recommendation to the Russian authorities: "To suspend implementation of the project, including the work permit until all relevant materials will not be considered"[11].

As mentioned, the entire cost of the project was now supposed to be covered by Gazprom.

The survey, conducted in 2008, showed increasing of the number of peoples supporting the construction. The Agency for Social Information, held a large survey (2,000 respondents). The study found that over the past two years the number of people supporting the construction of the public's business district "Okhta Center" in St. Petersburg had grown from 33 to 45\%. This is not surprising, because during the 2008 crisis, the economic importance of the Okhta Center has only increased.

Vladimir Putin noted at a press conference, that on the one hand, he realized the cultural importance of the region where the center was being constructed, but on the other hand he believed that the city needed "fresh air" centers, which would give opportunities for the development of the business activity. Putin also said that he understood the concerns of people against the construction and he shared this concerns, he did not claim that this is the best solution, but he did not want to influence the decision-making. [12, 13, 14].

Retrospective could represent the value and social willingness to this construction. So, it's easy to conclude, that profit from the Okhta Center and from saving the historical cityscape have the same value and importance for the city.

\subsection{Interviewing}

The building of the Okhta Center was closed in 2010. It is very interesting to know, how public opinion has been changing since the stopping of the erection. 
In the special interview the respondents were offered the following options concerning the land where the center was to be constructed:

- Removing layer by layer of all archaeological evidences in a special museum, while constructing a business center on this place;

- $\quad$ Building a museum on this place;

- The combination of the museum and business center on this place

- No action

- Disinterest;

All this options have their own pros and cons, opportunities and threats (SWOT). The description of it is presented in the Table 1 .

Table 1. SWOT analyzes

\begin{tabular}{|c|c|c|c|c|}
\hline Option & Strength & Weakness & Opportunity & Threat \\
\hline $\begin{array}{c}\text { Removing } \\
\text { layer by layer } \\
\text { of all } \\
\text { archaeological } \\
\text { evidences in } \\
\text { special } \\
\text { museum, after } \\
\text { it construct } \\
\text { business } \\
\text { center on this } \\
\text { place }\end{array}$ & $\begin{array}{l}\text { Saving of archeological } \\
\text { layers, creation of the } \\
\text { museum, creation of } \\
\text { working places in the } \\
\text { business center }\end{array}$ & $\begin{array}{l}\text { High expenses for } \\
\text { transportation and } \\
\text { construction of } \\
\text { detached building } \\
\text { for the museum, } \\
\text { disadvantages of } \\
\text { using of the } \\
\text { building square }\end{array}$ & $\begin{array}{l}\text { The improvement } \\
\text { of the social life } \\
\text { of the individual } \\
\text { district of Sankt- } \\
\text { Petersburg and } \\
\text { creation of big } \\
\text { numbers of } \\
\text { working places }\end{array}$ & $\begin{array}{l}\text { High expenses } \\
\text { for keeping the } \\
\text { building as the } \\
\text { museum, public } \\
\text { organization } \\
\text { critics because of } \\
\text { the location of } \\
\text { the business } \\
\text { center in the } \\
\text { historic area of } \\
\text { Sankt-Petersburg }\end{array}$ \\
\hline $\begin{array}{l}\text { The museum } \\
\text { on this place }\end{array}$ & $\begin{array}{l}\text { Keeping the city reputation, } \\
\text { availability for tourists }\end{array}$ & $\begin{array}{c}\text { High expenses for } \\
\text { construction of the } \\
\text { museum, } \\
\text { disadvantages of } \\
\text { using building } \\
\text { square, loosing } \\
\text { possible working } \\
\text { places }\end{array}$ & $\begin{array}{l}\text { The improvement } \\
\text { of cultural life of } \\
\text { the individual } \\
\text { district of Sankt- } \\
\text { Petersburg, small } \\
\text { number of } \\
\text { workplaces }\end{array}$ & $\begin{array}{l}\text { High expenses } \\
\text { for keeping the } \\
\text { building as a } \\
\text { museum, } \\
\text { stagnation in the } \\
\text { social life of the } \\
\text { region, }\end{array}$ \\
\hline $\begin{array}{l}\text { The } \\
\text { combination } \\
\text { of the } \\
\text { museum and } \\
\text { business } \\
\text { center on this } \\
\text { place }\end{array}$ & $\begin{array}{l}\text { Saving of archeological } \\
\text { layers, creation of the } \\
\text { museum, creation of } \\
\text { working places in business } \\
\text { center, opportunity to } \\
\text { upgrade the cultural level of } \\
\text { office workers, and } \\
\text { advantages of using the } \\
\text { building square }\end{array}$ & $\begin{array}{c}\text { High expenses, } \\
\text { long- term } \\
\text { building due to the } \\
\text { developing of both } \\
\text { projects }\end{array}$ & $\begin{array}{l}\text { The improvement } \\
\text { of cultural and } \\
\text { social life of the } \\
\text { district and city }\end{array}$ & $\begin{array}{l}\text { A big traffic jam } \\
\text { in this district, } \\
\text { air pollution }\end{array}$ \\
\hline No action & $\begin{array}{l}\text { Saving possibility of block } \\
\text { of flats construction, } \\
\text { possibilities for the erection } \\
\text { in the future }\end{array}$ & $\begin{array}{l}\text { Disadvantages of } \\
\text { the construction } \\
\text { square using and } \\
\text { losing interest for } \\
\text { cultural values of } \\
\text { Sankt-Petersburg, }\end{array}$ & $\begin{array}{l}\text { Possibility of the } \\
\text { community center } \\
\text { foundation for } \\
\text { improving social } \\
\text { level of life in } \\
\text { Saint Petersburg }\end{array}$ & $\begin{array}{l}\text { Losing cultural } \\
\text { value of great } \\
\text { importance, } \\
\text { regress of the } \\
\text { district due to } \\
\text { decreasing of } \\
\text { interest of } \\
\text { investors for this } \\
\text { area as the } \\
\text { potentially } \\
\text { possible project }\end{array}$ \\
\hline
\end{tabular}

Disinterest - this option shows the degree of the concern of peoples for this problem

Other - this option indicates the degree of awareness of people about the condition of the construction site, their knowledge of city development programs, as well as a willingness to participate in public life 


\subsection{Theoretical formulas}

More than 60 million rubles from the city budget were allocated in order to construct this building. Easy to prove that donation would recouped with more compact business-center and museum with a small cinema there would show films about history of Saint Petersburg, old Russian films etc.

The construction cost for $1 \mathrm{~m}$ of area in 2013 was about 30.5 thousand of rubles [15]. Now it would be about 43.5 thousands. It is mean that we could build about $1380 \mathrm{~m} 2$ of area (Sgen) with using only the city budget. The janitorial service of the building [16]:

$$
M_{\text {aintance }}=S_{\text {gen }} \cdot 22 \cdot f_{\text {dollar rate }}=1380 \cdot 22 \cdot 62
$$

Some calculation for counting of a payback:

$$
P_{\text {rofit }}=n \cdot 365_{\text {days }} \cdot k \cdot T_{1}+m \cdot 365_{\text {days }} \cdot k_{1} \cdot T_{2}
$$

$\mathrm{n}$ - the daily throughput of a museum. This coefficient depends on the size of the museum

$\mathrm{m}$ - the daily cinema throughput. This coefficient depends on numbers place in a movie hall

$\mathrm{k}$ - the average annual coefficient of the museum's room functioning capacity

$\mathrm{k} 1$ - the average annual coefficient of the cinema's room functioning capacity

T1 - the museum's ticket price

T2 - the cinema's ticket price

Souvenirs, excursions and DVD movie's sales in cinema could give:

$$
\Delta P=10 \% P
$$

All financial benefits could count such as:

$$
F_{\text {ull }} P_{\text {rofit }}=P+\Delta P
$$

Time will spent for the recoupment (in years):

$$
\begin{gathered}
N_{\text {et }} E_{\text {aring }}=F_{\text {ull }} P_{\text {rofit }}-M_{\text {aintance }} \\
T_{\text {ime }}=\frac{D_{\text {onation }}}{N_{\text {et }} E_{\text {aring }}}
\end{gathered}
$$

\section{Results and Discussion}

\subsection{Analyzes}

a)

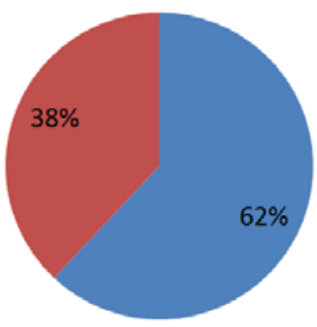

- lived in Sankt-Petersburg

- Did not live in Sankt-Petersb b)

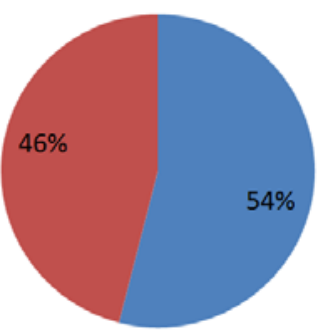

w $\mathrm{m}$

Figure1. (a) the location of respondents during Okhta proccess; (b) gender of interviewee 
- to $23 \quad$ from 24 to 35

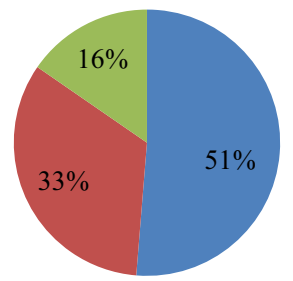

Figure 2. Diagram of the distribution answering of the respondents

The interview gave information about the gender of peoples and their location. A closer look at the data, which is presented on Figure 1, indicates that more than half interviewee didn't live on the territory of Saint Petersburg, so they couldn't participate in the social movement, so the decision about their integration in this problem during the conflict could be made.

That means that more than half people weren't involved in that problem at that time.

Gender of respondents just shows concern of peoples and their commitment.

The pie chart, demonstrated on Figure 2, shows the age of respondents, so, according this data, $51 \%$ of respondents was 18 and younger, $33 \%$ was between 19 and 30 years old, and $16 \%$ was in the age between 31 and 50 years old during the Okhta conflict.

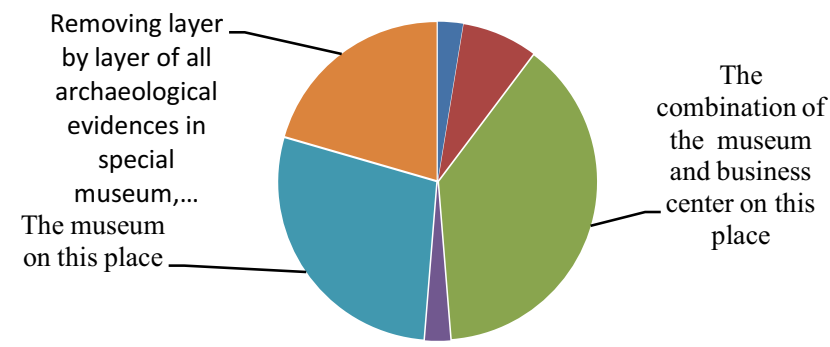

Figure 3. Diagram of the distribution answering of respondents/

The aim of this Figure 3 is to generalize the data and give the answer about the public estimation and involving in the proccess.

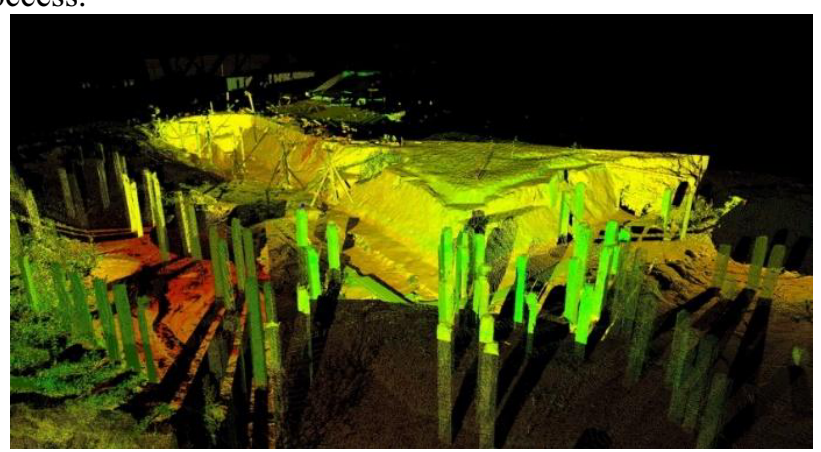

Figure 4. Results of the scanning [17, 18] 


\section{MATEC Web of Conferences}

Respondents, who chose "other" usually say about the creation of the museum inside Nyenschantz. But it is impossible. Now Nyenschantz is just a huge hill of stones. It is easy to see on Figure 3, results of the scanning. $[17,18]$.

About three tenth of the respondents would like to see only museum on this place.

More than one third of the respondents want to see combination if museum and business center on this place.
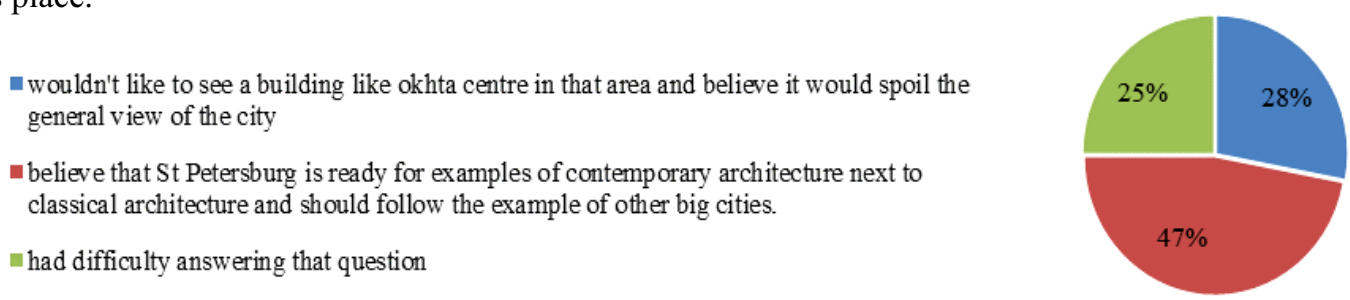

Figure5. Opinion of foreign guests of the city about the construction of a modern skyscraper in the historical center of city.

The last pie chart shows another view of this problem, from the side of foreign guests, who has the same project in their own countries.

\subsection{Practical formulas}

$$
M_{\text {aintance }}=S_{\text {gen }} \cdot 22 \cdot f_{\text {dollar rate }}=1380 \cdot 22 \cdot 62=1882320
$$

In Hermitage more than 12 thousands peoples, every day comes [19]. Of course, this museum one of the famous in the world, but it is real have more 600 people $\left(\mathrm{n}^{*} \mathrm{~T} 1\right)$ in day for the historical museum near the center, and $150\left(\mathrm{~m}^{*} \mathrm{~T} 2\right)$ people that come to the cinema every day. The average costs of tickets in the museum is less than 250 rubles [20], the same in the cinema [21]. Try to find time with using formulas (2-6):

$$
\begin{gathered}
P_{\text {rofit }}=600 \cdot 365_{\text {days }} \cdot 250+150 \cdot 365_{\text {days }} \cdot 250=68437500 \\
\Delta P=0.1 \cdot 68437500=6843750 \\
F_{\text {ull }} P_{\text {rofit }}=68437500+6843750=75281250 \\
N_{e t} E_{\text {aring }}=F_{\text {ull }} P_{\text {rofit }}-M_{\text {aintance }}=75281250-1882320 \\
T_{\text {ime }}=\frac{60000000}{73398930} \approx 0.8
\end{gathered}
$$

of year, or about 9 and half months.

\subsection{Projects}

One of the projects of the archeological museum on the Okhta Cape is represented as the already reconstructed model of Nyenschantz of XVII century. It would occupy all the area of the cape.

The museum includes few numbers of levels, one by one having expositions about the ancient times since Neolith Age to the times of Nyenschantz. 


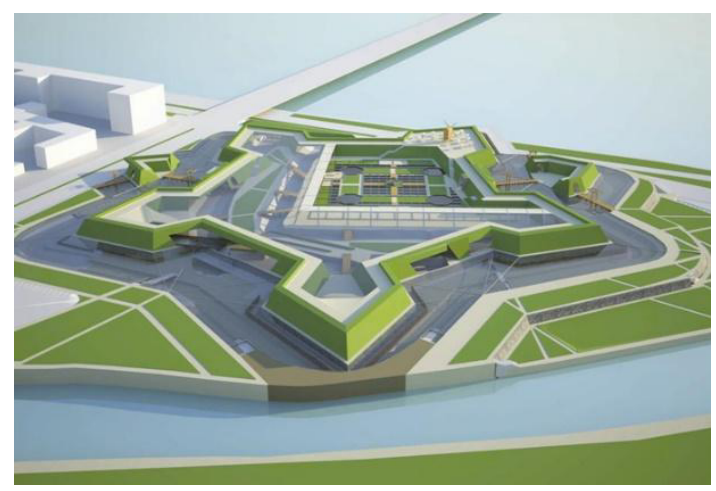

Figure 6. Visualization of the museum.

The layer, which was covered by the Yakornaya street, would be placed above the ground on special cantilevers. For free moving on Malookhtinskiy prospect could be built a podium with portecochere.
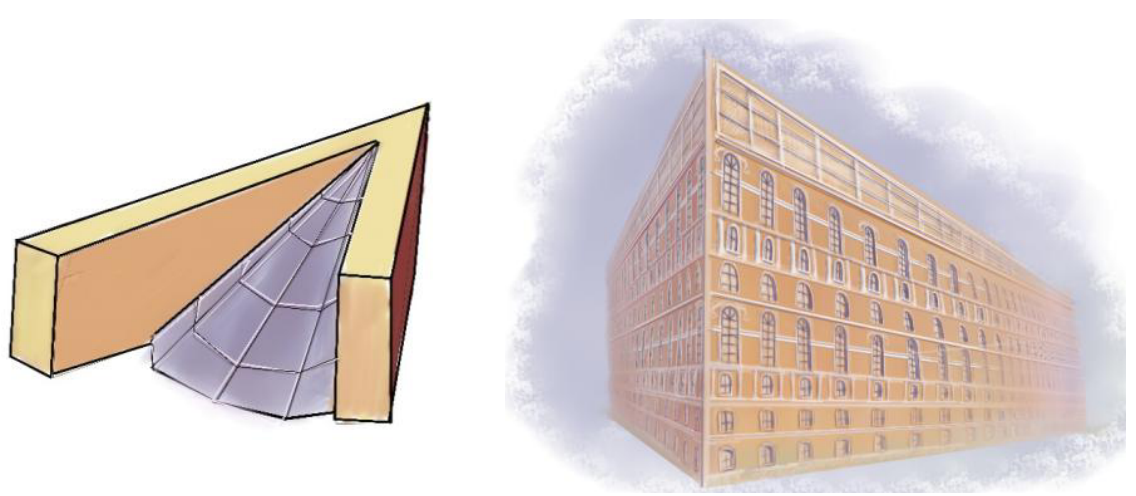

Figure7. The concept of the museum exterior.

The main question would be: what about the costs of building, and how it is possible without shutting off Malookhtinskij prospect and Yakornaya street [22]

Saint Petersburg needs to make workplaces and it couldn't spend a high volume of funds for it. The owner of this place wouldn't do it either, because of the low profit value of this place. In the same time the exterior is significant characteristic of the building, but Okhta Center had a playful name "corm". That factor shows the ratio of public to the appearance and understanding [23]. To such statements did not arise, it is necessary to clarify that: "Ergonomics is everywhere design. Aim of each architect should be the optimization and efficiency of the proposed design solutions " [24].

The idea of combination of the business center and the museum didn't need so much losses. Furthermore, it is possible to create also a big green zone closely to the center, because of using the shape of the cape, which looks like a spearhead. A huge dome made with long-span membrane helps to increase the solar affects [25] and to make sustainable [26].

After all, it will not only be beneficial to the environment. "Since A good planning of open space in the residential area will encourage people or the residents to spend more of their time at outdoor. Open space not only creates a meeting opportunities between the residents, but also can relief people from urban stresses and provided relaxation " [27].

The dome could be used as a museum, the main body of the building could be used as office area, first floor also could be used as a combination of the museum and the cinema with the small giftshop.

The erection of the building should start from the survey among the citizens, a big company that improves relationships between citizens and owners. We find it useful to make some briefings. 
Charity events open great opportunities to attract additional investments, and work well for the city reputation.

The most important and historically significant object distinguished, with connection to archeological, historical and culturological spheres will be located inside the Okhta museum. Some of the less valuable items should be located in other museums. In that time also the dome of the building will be constructed at the same time because of its unusual shape, which is sure to provide high durability and high level of solarization.

Later the building site discovered during excavations, must be saved for further investigation and future exhibitions. Then it is possible to start the erection of the center.

This building could be unique in Russia as a building joining old and new architecture not only as aesthetic and historical exterior.

We realize the possibility of certain problems, connected to: the disagreement of citizens; troubles with the excavations on the site; long construction process in case of complications during the construction of the dome; limitations in the amount of space because for aesthetic reasons; given the length of the building, it couldn't be a zero-building type, but it is possible to reduce the energy consumption. In addition, it is possible to use architecture properties of Saint Petersburg and make facade looks like natural parts of Saint Petersburg history by stylizing them in eclecticism style.

\section{Conclusion}

The data yielded by this paper provides convincing evidence that erection of building composition of museum and business center on this territory might give good benefits for Gasprom and for the city in general. The result of the research is also based on the public opinion.

The result of our work, is the view of the need to build on the territory of Okhta Cape, a complex consisting of a business center and a museum, our opinion was confirmed by the survey conducted in 2008 and, accordingly, in 2015. But to have an alternative point of view, it was also taken for the analysis of the second most popular option (museum). "Ergonomics is everywhere design. Aim of each architect should be the optimization and efficiency of the proposed design solutions". Each of these projects has pros and cons. From the cultural point of view, both options meet the moral needs of the city. From the practical point of view, the second project can satisfy not only moral needs of the citizens, but also help to improve the economical situation in the east of St Petersburg. "Ergonomics is everywhere design. Aim of each architect should be the optimization and efficiency of the proposed design solutions"

\section{References}

1. List of The World Heritage of UNECO

2. Littorina Sea. Brockhaus and Efron Encyclopedic Dictionary: to 86 m. (1890-1907)

3. Mesolithic and Neolithic EASTERN EUROPE: HISTORY AND CULTURAL INTERACTION International Conference on the 100th anniversary of NN Gurina. 182-199 (2012)

4. P. E. Sorokin, Science in Russia, 3, 19-25 (2011)

5. CORNERSTONE archeology, history, art and culture of Russia and neighboring countries. Institute of History of Material Culture RAS, 361-378 (2010)

6. L.N. Belova, G.N. Buldakov, A.J. Degtyarev St. Petersburg. Petrograd. Leningrad: Encyclopedic Reference (1992)

7. Target Program of Saint Petersburg "ADMINISTRATIVE BUILDING BUSINESS CENTER IN ST PETERSBURG",14, (2006)

8. «"Okhta Center "signed with the architects"' Business Petersburg »1606-1829 (Online) the pressservice company "Gazpromneft", (2007)

9. Law "On Amendments to the Law of St. Petersburg "On Target Program of St. Petersburg "Construction of administrative business center in St. Petersburg"

10. Official conference, cities with IA REGNUM 
11. Full text of the resolution of the 31st session of the World Heritage Committee of UNESCO on the convention dedicated to the preservation of world cultural and natural heritage, 116 (2007)

12. Official conference of Vladimir Putin, citing IA REGNUM

13. http://dic.academic.ru/dic.nsf/ruwiki/1081440

14. Online papers Fontanka: http://www.fontanka.ru/2007/01/29/115/

15. L. Lopatin, Vedomosti, 3457, (2013)

16. http://pax-romana.ru/projects/competitions/museum-131?lc=ru\

17. http://trimetari.com/images/projects/20101125_okhta/okhta_points_intensity_shaded.jpg

18. http://trimetari.com/ru/proekty/ohranno-spasatelnye-arheologicheskie-issledovaniya-naohtinskom-mysu-v-sankt-peterburge

19. Rossiyskaya Gazeta, 5059, (2007)

20. http://www.spb-guide.ru/page_13292.htm

21. According researching of NEVAFILM RESEARCH TM

22. E.V. Melnikova The project of creating the historical and archaeological museum on Okhta Cape

23. Bryan Lawson, Procedia - Social and Behavioral Sciences, 170, 545-550 (2015)

24. Klaudiusz Fross, Procedia Manufacturing, 3, 1625-1632 (2015)

25. Vera Murgul, Nikolai Vatin, Inna Zayats,Procedia Engineering, 117, 819-824, (2015)

26. Volodymyr Mushchanov, Yevgen Gorokhov, Arusyak Vardanyan, Margarita Kashchenko, Darya Nemova, Procedia Engineering, 117, 990-1000 (2015)

27. S. Yasmin Sofia Hussain, Ismail Said, Procedia - Social and Behavioral Sciences, 170, 545-556 (2015) 